\title{
The Characteristics of Children with UTI Due to ESBL-producing Bacteria at Dr. Soetomo General Academic Hospital, Surabaya
}

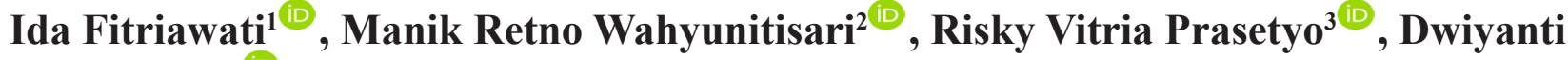 \\ Puspitasari $^{3^{*}(\mathbb{D})}$, Tuksin Jearanaiwitayakul ${ }^{4}$ \\ ${ }^{1}$ Faculty of Medicine Universitas Airlangga, Surabaya, Indonesia \\ ${ }^{2}$ Department of Microbiology, Faculty of Medicine, Universitas Airlangga, Surabaya, Indonesia \\ ${ }^{3}$ Department of Pediatrics, Faculty of Medicine, Universtas Airlangga - Dr. Soetomo General Academic Hospital, Surabaya, \\ Indonesia \\ ${ }^{4}$ Department of Microbiology, Faculty of Science, Mahidol University, Bangkok, Thailand
}

\section{A R T I C L E I N F O}

\section{Article history:}

Received 10 March 2021

Received in revised form 15 June 2021

Accepted 23 June 2021

Available online 30 June 2021

\section{Keywords:}

Urinary tract infection,

Extended-spectrum beta-lactamase, Characteristic,

Pediatric.

\section{*) Corresponding author:} dwiyanti-p@fk.unair.ac.id

\begin{abstract}
A B S T R A C T
Introduction: Urinary tract infection (UTI) by extended-spectrum beta-lactamase-producing bacteria often results from a delay in treatment with appropriate antibiotics. The information on patients' clinical profiles may be beneficial for the selection of antibiotics used in empirical therapy. Thus, this study aims to investigate the clinical characteristics and the duration of antibiotic therapy in the pediatric patients with urinary tract infections by those resistant bacteria.

Methods: This study utilizes a cross-sectional design. Medical records of hospitalized children aged 1-18 months with UTI due to ESBL-producing bacteria at Dr. Soetomo General Academic Hosptal between January 1, 2017 - July 20, 2020, were collected and reviewed retrospectively. Medical records including the demographic data, underlying diseases, causative organism, clinical presentation, maximal body temperature, and length of antibiotic therapy were used as variable paramenters of interest in this present study.

Results: Among 37 patients enrolled, 25 patients were female. The incidence of urinary tract infection was mostly reported in children aged 1-12 months old (37.8\%). Urological abnormalities were presented in $62.2 \%$ of patients and ESBL-producing Escherichia coli was the most common causative agent isolated from the patients (62.2\%). A high fever was found in 10/28 patients (35.7\%). In 17 patients (45.9\%), the total duration of antibiotic therapy was 8-14 days.

Conclusion: In children with UTI, especially in the infant group, who had urological abnormality or present with a high fever, and who do not respond to empiric therapy should be suspected of developing UTI due to ESBL-producing bacteria.
\end{abstract}

\section{Introduction}

Urinary tract infection is characterized by the significant growth of pathogenic microorganisms in the urinary tract. ${ }^{1}$ This infection is quite common in children. A study by Masika et al. found that the overall prevalence of UTI in children aged 2 months -5 years in Western Kenya was $11.9 \% .^{2}$ The risk of infection can be augmented in certain conditions, such as age under 3 months, uncircumcised males, malnutrition, and constipation. ${ }^{3}$

The prevalence of urinary tract infections in children by antibiotic-resistant bacteria has been reported in many studies. For instance, Nazmi et al., revealed that an overall prevalence of UTI caused by ESBL Escherichia coli and Klebsiella pneumoniae were $35 \%$ and $45 \%$, respectively, in a private hospital in Tangerang. ${ }^{4}$ A study in Lebanon showed that $15.5 \%$ of UTI cases in children under 18 years were caused by ESBL-producing organisms, with the bacterial species of E. coli and Klebsiella spp. ${ }^{5}$ Similar to the finding conducted at Dr. Soetomo General Academic Hospital, Muhajir et al., found that cases of pediatric UTI by ESBL-producing bacteria were caused by Escherichia coli (in $37.5 \%$ of cases), followed by Klebsiella pneumoniae (in $60.7 \%$ of cases), and Klebsiella oxytoca (in 1.8\%).6 Another study by Hyun et al., also reported that ESBL-producer is the major causative agent for UTI cases in children under 2 years old $(17.3 \%)^{7}$

The infection with ESBL producing bacteria potentially results in failure in the initial phase of empirical antibiotic treatment. 8 Consequently, it could lead to an increase in morbidity. This is supported by a study reported by Al- 
otaibi et al. in central Saudi Arabia, UTI due to ESBL bacteria positively associates with increase mortality when compared to non-ESBL UTIs. ${ }^{9}$

In Indonesia, the contribution of clinical characteristics, especially concerning age distribution, underlying diseases, and maximal body temperature to etiology of UTI caused by ESBL-producing bacteria is still lacking. This study aims to determine the clinical characteristics of pediatric UTI patients with resistant bacteria. The information reported in this study expectedly could promote early recognition and encourage more detail for future research on the identification of potential clinical characteristics that associates with ESBL-producing bacteria mediated UTI .

\section{Methods}

This study was a descriptive study using a cross-sectional design. The medical records of hospitalized children with UTI in the Inpatient Installation on the Department of Child Health, Dr. Soetomo Surabaya General Hospital from 1 January 2017 up to 20 July 2020 were reviewed retrospectively. The subjects were included using consecutive sampling with the following criteria: (1) children aged 1 month - 18 years; (2) final diagnosis of UTI based on medical record; (3) confirmed to have positive urine culture for ESBL-producer. Patients with coinfection or incomplete medical records were excluded.

The data of demographic characteristics, underlying disease, confirmed pathogen, clinical manifestation, maximal body temperature, and length of antibiotic therapy, were retrieved from medical records. The data on causative organisms were kindly obtained from urine culture results at the Laboratory of Clinical Microbiology, Dr. Soetomo General Academic Hospital Urine specimens for the UTI diagnosis included a mid-portion urine or urine catheter. An antimicrobial sensitivity test was performed using the disk diffusion method. Meanwhile, the identification for ESBL was done by double disk synergy test with a confirmatory test using the Phoenix ${ }^{\circledR}$ system following the Clinical and Laboratory Standards Institute (CLSI). The data were then entered into a data collection form. The categorical data were reported as frequency and percentage.

This study was approved by the Health Research Ethics Committee with certificate no. 1430 / KEPK / VIII / 2019.

\section{Results}

During the study period, 37 out of 156 hospitalized pediatric patients with UTI caused by ESBL-producing bacteria were included in the final data analysis. Demographic data, underlying disease, and type of causative pathogens from subjects were shown in table 1 . The median age of subjects was 23 months old, ranging from 3 to 180 months. Based on age of child development, the majority cases of UTI caused by ESBL-producing bacteria were revealed in infant group aged $1-12$ months, which was accounted for $37.8 \%$ of patients. In addition, among overall subjects, the high proportion of cases was reported in female $(67.6 \%)$ (Table 1$)$.

Most patients admitted at Dr. Soetomo General Academic Hospital accompany with one or more comorbid diseases. Urological abnormality was the most commonly disorder as evidenced by $62.2 \%$ of patients. This abnormality includes renal dysgenesis, hydronephrosis, neurogenic bladder, ureterovesical junction obstruction, vesicoureteral reflux, and acute kidney injury (Table 1.). Among the bacterial pathogens isolated, Escherichia coli was the most frequencies of causative pathogen isolated from pediatric patient with UTI as shown by 23 out of 37 patients $(62.2 \%)$. This is followed by Klebsiella pneumonia $(13 / 37$ patients or $35.1 \%)$.

Table 1. Demographic data, underlying disease, and pathogen from patients with UTI due to ESBL-producing bacteria $(n=37)$.

\begin{tabular}{lcc}
\hline Characteristic & $\mathrm{n}$ & $\%$ \\
\hline Age & & \\
\hline $1-12$ month & 14 & 37.8 \\
\hline$>1-3$ years & 7 & 18.9 \\
\hline$>3-6$ years & 5 & 13.5 \\
\hline$>6-12$ years & 7 & 18.9 \\
\hline$>12-18$ years & 4 & 10.8 \\
\hline Gender & & \\
\hline Male & 12 & 32.4 \\
\hline Female & 25 & 67.6 \\
\hline Underlying disease & & \\
\hline Urological abnormality & 23 & 62.2 \\
\hline Non-urological abnormality & 31 & 83.8 \\
\hline None & 2 & 5.4 \\
\hline Causative organism & & \\
\hline E. coli & 23 & 62.2 \\
\hline K. pneumoniae & 13 & 35.1 \\
\hline K. oxytoca & 1 & 2.7 \\
\hline
\end{tabular}

Clinical characteristic and treatment duration of subjects were also studied and shown in table 2 . The majority of UTI cases developed fever (81.1\%). However, asymptomatic bacteriuria was found in only 1 patient $(2.7 \%)$ (Table 2 ). The maximal body temperature was further divided into three categories. Fever with an axillary temperature of $38.5^{\circ} \mathrm{C}$ or more was reported in $11 / 28$ patients $(39.3 \%)$ and most of UTI cases in the present study required length of antibiotic therapy ranging from 8 up to 14 days (45.9\%) (Table 2).

Table 2. Clinical characteristics and length of antibiotic therapy among subjects $(n=37)$.

\begin{tabular}{lcc}
\hline Variables & $\mathrm{N}$ & $\%$ \\
\hline Clinical presentation & & \\
\hline Fever & 30 & 81.1 \\
\hline Focal urologic symptom & 15 & 40.5 \\
\hline Vomiting & 10 & 27 \\
\hline Abdominal pain & 7 & 18.9 \\
\hline Diarrhea & 1 & 2.7 \\
\hline Asymptomatic & 1 & 2.7 \\
\hline
\end{tabular}




\begin{tabular}{lcc}
\hline Maximal body temperature $\left({ }^{\circ} \mathbf{C}\right)^{*}$ & & \\
\hline$<37.5^{\circ} \mathrm{C}$ & 7 & 25.0 \\
\hline $37.5-<38.5^{\circ} \mathrm{C}$ & 10 & 35.7 \\
\hline$\geq 38.5^{\circ} \mathrm{C}$ & 11 & 39.3 \\
\hline Length of antibiotic therapy & & \\
\hline$\leq 7$ & 7 & 18.9 \\
\hline $8-14$ & 17 & 45.9 \\
\hline$>14$ & 13 & 35.1 \\
\hline
\end{tabular}

*the data were obtained from 28 patients

\section{Discussion}

The present study reported that the proportion of UTI due to ESBL-producing bacteria was dominated in females. This observation have also been reported in previous studies..$^{5,10,11}$ In agreement with those studies, UTI cases among infants aged 1-12 months were predominantly found in female. On the other hand, Kim et al., has revealed that most of the cases in community-acquired urinary tract infection (CAUTI) caused by ESBL bacteria occure in male infants. ${ }^{12}$ Interestingly, Marco et al., has revealed that infants with UTI by ESBL-producer were also girls (84\%). ${ }^{10}$ Madhi et al., in their research involving children aged $0-18$ years old in France also found that male accounted 135 out of 301 patients (44.5\%). This is suggested that an ESBL-associated UTI in pediatric population are potentially associated with female gender. Different finding might be possible due to variation of population characteristic involved in a study, since male infants with phimosis or uncircumscribed, are at a higher risk of UTI. ${ }^{13}$

Patients included in our study could have more than one underlying disease. However, in general, we found that the proportion of patients with the urological abnormality amounted to $62.2 \%$. Previous study has also stated that renal and urinary tract anomaly are comorbidity that frequently occures in patients with UTI by ESBLproducing bacteria. ${ }^{14-17}$ In the study by Lagree et al., the frequency of that anomaly was $30 \%$ among children aged 1 month to 16 years. ${ }^{15}$ Higher frequency up to $57 \%$ was found in the ESBL-associated UTI cases among $\leq 14$ years old in France, ${ }^{16}$ indicating that most cases were categorized in complicated UTI ${ }^{18}$ The presence of anomalies in urinary tract might act as a bacterial reservoir, which further increases the risk of recurrent infection or relapse. ${ }^{7,19}$ Besides, the presence of comorbidities might be related to a history of hospitalization or invasive procedures that enable patients to acquire infection of resistant bacteria from the hospital. ${ }^{20,21}$

The most identified organism in our study were $E$. coli and $K$. pneumoniae. This finding was consistent with the study conducted by Muhajir et al., from January-June 2014 at RSUD Dr. Soetomo and the study by Hyun et al., involving children 0-24 months in Seoul., ${ }^{6,722}$ Apart from those pathogenic bacteria, we also observed that $K$. oxytoca was isolated from one of pediatric patients. Study by Madhi et al., on children under 18 years, primary uropathogen were E. coli, accounting for $87.8 \%$ of study population. ${ }^{14}$ Small proportions of UTIs due to ESBL-producer in children were caused by other species, such as Enterobacter cloaca, Citrobacter koseri, and Klebsiella oxytoca. ${ }^{14}$

The clinical manifestations of UTI generally vary and depend on several factors, such as age and specific location of the infection. ${ }^{23}$ We found that $81.1 \%$ of cases experienced with fever. A similar finding was reported by Tratselas et al., which involved children $\leq 14$ years of age in Greece. ${ }^{24}$ In general case of children with UTI, fever was recognized as primary symptoms..$^{25}$ Research by Dotis et al., however, has revealed that symptoms including flank or abdominal pain, diarrhea, vomiting, anorexia were more commonly than fever in their subjects. ${ }^{26}$ Another study by Park et al., has shown that gastrointestinal symptoms was observed in only $17 \%$ patients aged under 5 years with febrile ESBL- associated UTI. ${ }^{27}$ This finding probably was due to differences in the age distribution of the subjects, since children under 2 years still cannot verbalize some symptoms, such as dysuria, enuresis, and abdominal pain. ${ }^{28}$ As a result, it could not be evaluated.

As stated in the literature, high fever $\left(>39^{\circ} \mathrm{C}\right)$ is the indication of upper UTI. ${ }^{28}$ Our study found that fever $\geq 38.5^{\circ} \mathrm{C}$ dominates the maximal temperature of subjects (39.3\% of patients). This is supported by previous study in which reported the average of maximal temperature recorded from patients aged 0-16 years with UTI due to ESBL-producing bacteria is $38.9 \pm 1.29$ oC.29 Research done by Marco et al., has also shown that maximal temperature found in children under 2 years with ESBL UTI has a mean of $39.2^{\circ} \mathrm{C}$. ${ }^{10}$ This finding implies a possibility of most patients with ESBL-associated UTI in this research that may experience with acute pyelonephritis. Study by Hong et al., among children under 36 months with UTI due to ESBL-producing bacteria found that median peak temperature is about $38.9^{\circ} \mathrm{C}$, with interquatile range $38.4^{\circ} \mathrm{C}-39.3^{\circ} \mathrm{C}$, but this did not differ significantly with that of non-ESBL UTI.30 Therefore, a more comprehensive study with diagnostic imaging to confirm this finding is recommended.

UTI due to resistant bacteria often requires an escalation of antibiotics with adjustment to antibiotic sensitivity test and clinical response. In our study, typically patients required 8 to 14 days course of antibiotics. A study conducted by Han et al. showed that the duration of total antibiotic administration in the ESBL group was significantly longer than the non-ESBL group, in which the median duration of therapy was 14 days.31 Research by Fan et al., on children under 15 years with UTI caused by ESBL-producing bacteria, revealed that mean duration of antibiotic therapy was around 9.7 days. ${ }^{32}$ The infection caused by ESBL-producing bacteria was much more frequently in failure of antibiotic treatment. ${ }^{10}$ According to study by Macvane et al., up to $61.8 \%$ cases of UTI due to these resistant bacteria failed in an initial phase of antibiotic treament. ${ }^{8}$ These mean that time to administer an appropriate antibiotic which could bring a clinical improvement is often prolonged. ${ }^{8}$ According to the Consensus of Urinary Tract Infection in Children 2011, parenteral antibiotic administration between 7-14 days usually required in the case of acute pyelonephritis. ${ }^{33}$ Since the majority of UTIs were complicated (occurred in patients with an abnormality of the kidney and urinary tract), therefore, the inadequate administration of antibiotics might lead to relapse of disease progression. 
This study, however, is subject to several limitations. Due to the cross-sectional design, some medical records have to be excluded because of incomplete data. However, information reported in this research could introduce the important clinical characteristics of ESBL-associated UTI in children and could also promote further research.

\section{Conclusion}

In pediatric patients, urinary tract infection due to ESBLproducing bacteria was dominated by age $1-12$ months with a female predominance. Most patients presented with high fever $\left(38.5^{\circ} \mathrm{C}\right.$ and above) and developed urological diseases. Therefore suspicion of UTI due to ESBLproducing bacteria should arise when these criteria were met in a patient. A further prospective study and that involving more subjects is needed to confirm the findings.

\section{Conflict of Interest}

The author stated there is no conflict of interest

\section{References}

1. Pardede SO. Infeksi pada Ginjal dan Saluran Kemih Anak: Manifestasi Klinis dan Tata Laksana. Sari Pediatr 2018; 19: 364-74.

2. Masika WG, Meara WPO, Holland TL, et al. Contribution of urinary tract infection to the burden of febrile illnesses in young children in rural Kenya. 2017; 1-13.

3. Almofarreh M, Alowaa Z, Junainah E, et al. Prevalence of urinary tract infection among children. Int J Contemp Pediatr 2018; 5: 2356.

4. Nazmi M, Made N, Mahardik A, et al. Kejadian Infeksi Saluran Kemih oleh Bakteri Escherichia coli dan Klebsiella pneumoniae Extended Spectrum Beta Lactamase: Studi Kasus di Rumah Sakit Swasta Periode 2012-2015 The Prevalence of Urinary Tract Infection Caused By Extended Spectrum Case Study . 23.

5. Hanna-Wakim RH, Ghanem ST, El Helou MW, et al. Epidemiology and characteristics of urinary tract infections in children and adolescents. Front Cell Infect Microbiol 2015; 5: 1-8.

6. Muhajir AS, Purwono PB, Handayani S, et al. Gambaran Terapi dan Luaran Infeksi Saluran Kemih oleh Bakteri Penghasil. 2016; 18 : 111-116.

7. Hyun HS, Kim JH, Cho MH, et al. Low relapse rate of urinary tract infections from extended-spectrum beta-lactamase-producing bacteria in young children. Pediatr Nephrol 2019; 34: 2399-2407.

8. Macvane SH, Tuttle LO, Nicolau DP. Impact of extended-spectrum $\beta$-lactamase-producing organisms on clinical and economic outcomes in patients with urinary tract infection. J Hosp Med 2014; 9: 232-238.

9. Al-otaibi FE, Bukhari EE. Clinical and laboratory profiles of urinary tract infections caused by extended-spectrum beta-lactamaseproducing. 2013; 34: 171-176.

10. Hernández Marco R, Guillén Olmos E, Bretón-Martínez J, et al. Community-acquired febrile urinary tract infection caused by extended-spectrum beta-lactamase-producing bacteria in hospitalised infants. Enferm Infecc Microbiol Clin 2017; 35: 287292.

11. Said M, Ghanem S, Rajab M, et al. Pediatric Risk Factors and Characteristics of Urinary Tract Infections caused by ESBL versus Non-ESBL Organisms at Makassed General Hospital. Eur J Biomed Pharm Sci 2018; 5: 29-34.

12. Kim YH, Yang EM, Kim CJ. Urinary tract infection caused by community-acquired extended-spectrum beta-lactamase-producing bacteria in infants. J Pediatr (Rio J) 2017; 93: 260-266.

13. Arshad M, Seed PC. Urinary Tract Infections in the Infant. Clin Perinatol 2015; 42: 1-16.

14. Madhi F, Jung C, Timsit S, et al. Febrile urinary-tract infection due to producing Enterobacteriaceae in children : A French prospective multicenter study. PLoS One 2018; 13: 1-14.

15. Lagree M, Bontemps S, Dessein R, et al. Extended-spectrum $\square$-lactamase-producing Enterobacteriaceae, national study of antimicrobial treatment for pediatric urinary tract infection $\square .2018$; 48: 193-201.

16. Heras IP, Sanchez-Gomez JC, Beneyto-Martin P, et al. Community- onset extended-spectrum b-lactamase producing Escherichia coli in urinary tract infections in children from 2015 to 2016. Medicine (Baltimore) 2017; 96: 1-3.

17. Amornchaicharoensuk Y. Clinical characteristics And Antibiotic Resistance Pattern of Pathogens In Pediatric Urinary Tract Infection. SoutheaSt aSian J trop Med public Heal 2016; 47: 976-982.

18. Parasuraman R, Julian K. Urinary tract infections in solid organ transplantation. Am J Transplant 2013; 13: 327-336.

19. Chang SL, Shortliffe LD. Pediatric Urinary Tract Infections. Pediatr Clin North Am 2006; 53: 379-400.

20. Hu YJ, Ogyu A, Cowling BJ, et al. Systematic Systematic reviews reviews Available evidence of antibiotic resistance from extendedspectrum $\beta$-lactamase-producing Enterobacteriaceae in paediatric patients in 20 countries : a systematic review and meta-analysis. 2019; 486-501.

21. Horie A, Nariai A, Katou F, et al. Increased community-acquired upper urinary tract infections caused by extended-spectrum betalactamase-producing Escherichia coli in children and the efficacy of flomoxef and cefmetazole. Clin Exp Nephrol 2019; 23: 1306-1314.

22. Shettigar S, Chandrashekar GS, Roche R, et al. Bacteriological profile, antibiotic sensitivity pattern, and detection of extended-spectrum $\beta$-lactamase in the isolates of urinary tract infection from children. Indian J Child Heal 2016; 3: 27-31.

23. Miesien M, Tambunan T, Munasir Z. Profil klinis Infeksi Saluran Kemih pada Anak di RS Dr. Cipto Mangunkusumo. Sari Pediatr 2006; 7: 200 .

24. Tratselas A, Iosifidis E, Ioannidou M, et al. Outcome of Urinary Tract Infections Caused By Extended Spectrum Beta-LactamaseProducing Enterobacteriaceae in Children. Pediatr Infect Dis J 2011; 30: 707-709.

25. Adegun P., Ajite A., Oluwayemi I., et al. The Clinical Characteristics of Childhood Urinary Tract Infection in Ekiti State University Teaching Hospital, Ado Ekiti, Nigeria. Niger Stethosc 2020; 2: $21-$ 27.

26. Dotis J, Printza N, Marneri A, et al. Urinary tract infections caused by extended-spectrum betalactamase- producing bacteria in children: A matched casecontrol study. Turk J Pediatr 2013; 55: 571-574.

27. Park SY, Kim JH. Clinical Significance of Extended-spectrum $\beta$-lactamase-producing Bacteria in First Pediatric Febrile Urinary Tract Infections and Differences between Age Groups. Child Kidney Dis 2017; 21: 128-135.

28. Feld LG, Mattoo TK. Urinary Tract Infections and Vesicoureteral Reflux in Infants and Children. 31.

29. Megged O. Extended-spectrum $\beta$-lactamase-producing bacteria causing community-acquired urinary tract infections in children. Pediatr Nephrol 2014; 29: 1583-1587.

30. Hong S, Kim H, Chueh HW. Clinical characteristics of children who visited the emergency department with extended-spectrum betalactamase-producing Escherichia coli urinary tract infection and its risk factors. Pediatr Emerg Med J 2020; 7: 101-107.

31. Han SB, Lee SC, Lee SY, et al. Aminoglycoside therapy for childhood urinary tract infection due to extended-spectrum $\beta$-lactamaseproducing Escherichia coli or Klebsiella pneumoniae. BMC Infect Dis 2015; 15: $1-8$.

32. Fan NC, Chen HH, Chen CL, et al. Rise of community-onset urinary tract infection caused by extended-spectrum $\beta$-lactamase-producing Escherichia coli in children. J Microbiol Immunol Infect 2014; 47: 399-405.

33. Ikatan Dokter Anak Indonesia. Konsensus Infeksi Saluran Kemih pada Anak. Jakarta: Badan Penerbit Ikatan Dokter Anak Indonesia, 2011. 